\title{
Stylistic Evolution of Wooden Idols: Changing Faces of History in Bengal Art
}

\author{
Sanjay Sen Gupta \\ School of Fine Arts, Amity University Kolkata, India. Email: sanjaysg1974@gmail.com \\ Received April 28, 2017; Revised July 14, 2017; Accepted July 15, 2017; Published August 23, 2017.
}

\begin{abstract}
Idols, i.e., divine images for worship, have always been an important component of Indian sculpture. Throughout the ages, these idols have simultaneously been carved in wood and stone - however the history of wood dates back much earlier than the other. But, the perishable nature of the material and the hot-andhumid climate of the subcontinent didn't allow the wooden-specimens to survive till date. Hence the rich and varied tradition didn't get their due importance in the prevailing texts dealing with the history of Indian art. This paper hence attempts to come up with a comprehensive account on the same in order to enable a broader perspective of Indian art and enhance the scopes of further research and discoveries. The methodology included both field-study and academic-research that resulted into a comprehensive overview of this artistic evolution - through the ages - against the panorama of Bengal art.
\end{abstract}

Keywords: Wooden idols, Bengal, India.

\section{Introduction}

Bengal, as a historical and cultural notion, comprises with today's Indian-state of West Bengal and the neighboring-country of Bangladesh. The art of this soil, alias that of mainland-India, has always been closely connected with religion - illuminating its aspects in each and every step. Ritualistic practices of this soil have always reflected the collective aesthetic sense of the people through various modes of visual-expression. Among them, the tradition of making idols - i.e., divine images for worship - has been one of the most profound and significant one.

Since an early time, though not identified yet, these religious-idols have been made of clay, stone, metal and other plastic-mediums; while wood in particular was preferred for its easyavailability and ready-tractability. (Dasgupta, 1990) But the perishable-nature of the material intrigued by the hot and humid climate of the region - didn't allow the earlier-specimens to survive till date. In any case, plenty of other resources testify the antiquity of making wooden idols within the panorama of Indian art. (Coomarswamy, 1972) Mostly carved in-the-round and occasionally in high-relief - these images were installed in the sanctum of the shrine either independently or in a group. All of them constitute a long traditional ancestry, beginning from c. sixth century $\mathrm{BC}$ - if not earlier - which has evolved through the ages to be found alive even today.

Early References to Wooden Idol: The earliest mention of any wooden idol made in India goes to the legend of Jìvantasvāmì - a sandalwood-image of Mahāvīra - that was said to be carved in

(c) AesthetixMS 2016. This Open Access article is published under a Creative Commons Attribution Non-Commercial 4.0 International License (http://creativecommons.org/licenses/by-nc/4.o/), which permits non-commercial re-use, distribution, and reproduction in any medium, provided the original work is properly cited. For citation use the DOI. For commercial re-use, please contact editor@rupkatha.com. 
his lifetime and worshipped by his followers. Refer could also be made of the tradition of Yakșa Moggarāpāni outside the city of Rājagrha - i.e., today's Rajgir in Bihar. (Dasgupta, 1990)

Later in second century AD, Matsya Purāna (Agrawala, 1963) is found as the earliest textual-reference - describing wood as a suitable medium for the sculpting of cult-icons. (Tarkaratna \& Nyayateertha, BS 1394) But the first concrete-evidence to this tradition comes from the third-century inscription of Abhirā Vāsudeva that describes Aștabhujasvāmī - an eight-armed wooden-sculpture of Lord Vișnu. (Chakraborti, 2001)

For the next six-hundred odd years, the tradition continued with all its vitality and context - and was documented in a series of indigenous literature like Mānasara Silpaśástra, Hayaśírșa Pañcarātrama, Devī Purāṇa, Vrhat Samihitā, Śāmba Purāṇa, Bhaviṣya Purāna and Vișñudharmottaram. Mention could also be made of the historical accounts by foreign-travelers like Huen Tsang, who referred to a sandal-wood image of Kuan-tzu-tsai Pusa, i.e., Avalokiteśvara. (Watters, 1961) Three more sandal-wood images of Lord Buddha were taken by him back to China, (Samaddar \& Ghosh, 1988) traces of which remain unspecified yet. These references however advocate in favor of wood to be used in the making of Buddhist-icons during late-sixth or early-seventh century AD.

Continuation of this lineage is later substantiated by a freestanding-sculpture of Tārā that was found from cave XXXI at Kanheri, near Mumbai of Maharashtra. In terms of iconography and style, it belongs to c. ninth-tenth century AD and is considered to be an import from easternIndia (see Fig 1). However, its present location is yet unknown, while a photograph - published in Marg (36/1, 1982) - remains the only evidence, reminding about the Päla-figures from Bihar and Bengal. Similar Buddhist-icons - collected in a monastery at Chittagong, Bangladesh - ranging in date from about ninth to twelfth-thirteenth century AD, (Spooner, 1990) could also be mentioned in this regard.

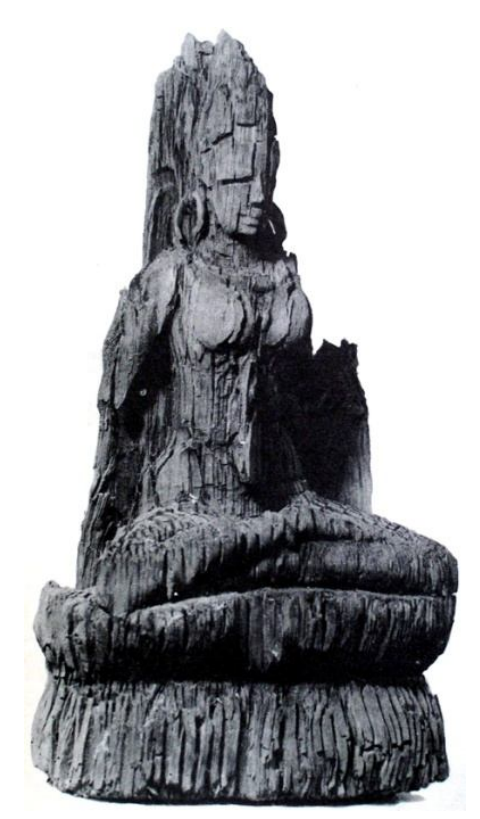

Fig 1. Buddhist Tärā, c. $9^{\text {th }}-10^{\text {th }}$ cent., $24 \times 10 \times 8$ in., present location unknown.

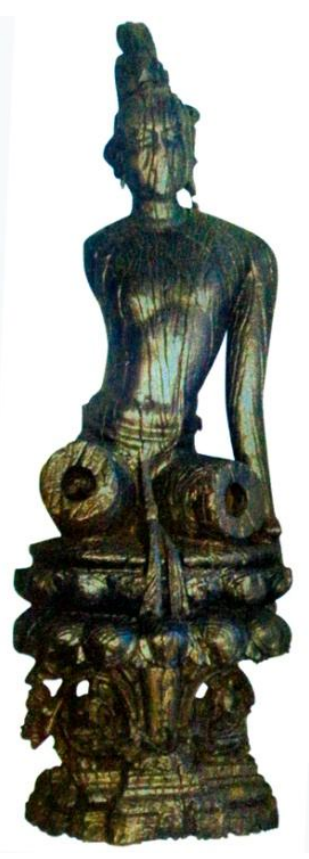

Fig 2. Bodhisattva Lokanātha, c. $9^{\text {th }} / 1^{\text {th }}$ cent., $49 \times 17$ in., BNM, Dhaka.

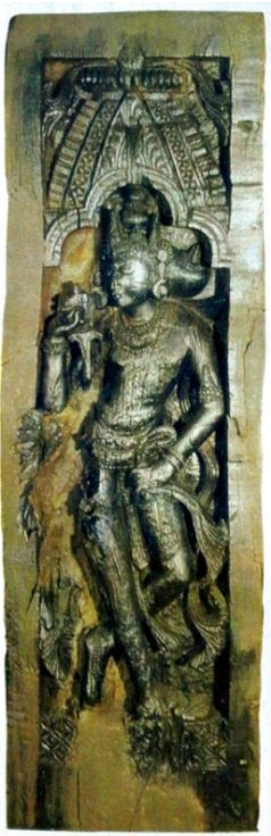

Fig 3. Sthiracakra Mañjuśrī, c. $1{ }^{\text {th }}$ cent., $54 \times 16$ in., BNM, Dhaka. 
The Earliest Specimen: Most Indian wooden idols of perceptible antiquity and aesthetic excellence - either originate, or belong to the eastern-region of this country. Earliest of this genre is the Tārā-image mentioned above; while the Bodhisattva Lokanātha from Tongibari of Munshigunj in Dhaka (today's Bangladesh) is the oldest of the surviving specimens (see Fig 2). In terms of form and style, both the figures bear a striking similarity with each other that lead towards the latter to be assigned to c. ninth-tenth century AD. Yet official records attribute a much later date - i.e., the eleventh - making Lokanātha contemporary to the Sthiracakra Mañjuśrī from Rampal, also in Munshigunj (see Fig 3). In that case, both the specimens - presently on display at Bangladesh National Museum, Dhaka - become contemporaneous with the tradition of Balarāma-Subhadrā-Jagannātha of Puri in Orisssa.

The refined approach and stylistic maturity of these earliest surviving wooden idols affirm a high quality practice, generated by an extremely old and rich traditional ancestry. It must have a long history of evolution, though undocumented, which took shape in c. AD 800 and resulted into a new school of Indian-sculpture in the eastern-provinces. (Banerji, 1933 and Asher, 1980)

\section{Wooden Idols of Bengal: the early stage}

The wooden idols of Bengal admit three broad stylistic divisions: hieratic, folk-tribal and a mixture of the two. (Dasgupta, 1990) The first one emerged in the urban-settlements constituting the earliest body of works, while the second came up from the pastorals and joined the lineage sometime between the thirteenth and fifteenth century. The last one, however, evolved in the sixteenth - introducing a new visual language and aesthetics.

Historically, Bengal has always maintained its own cultural identity that was closely associated with the proceedings in the mainland. Multiple terracotta-pieces and works in other mediums showcase the influence of pan-Indian phenomena on the hieratic level of early-Bengal art. Various available specimens kept in different Museums clearly advocate in favor of a distinct influence on the aesthetics of this soil that has borrowed relentlessly from the Maurya and Sungatraditions.

Following this pan-Indian dynamics, hieratic tradition of wooden idols in Bengal came to the fore only in the middle ages - during the rule of the mighty Mauryas. Although no material specimen has been found till date, but other references advocate in favor of this forgotten episode.

By that time, Bengal was already in high-demand for its woodcarving-techniques, designs of wooden-construction, (Craven, 2001) the skilled carvers and the experienced architects. (Havell, 1915) Many of these artisans were working in the mainland in ambitious projects that required their knowledge and skill in the works of wood. In this process, they developed a close proximity with the political, economic, artistic and cultural activities in the mainland. Hence they must have observed and studied the uninterrupted-lineage that connected the Jivantasvāmi of sixth-century BC with the Aștabhujasvāmì of third-century AD. This close association must have inspired them to try their hands back home in carving their own icons in wood. Their skill and effort must have produced various wooden-divinities meant for worship - that, unfortunately, couldn't survive the corroding effects of time.

In parallel to this, the folk-tribal genre of divine images in Bengal was always active in cheaper-mediums like clay and natural-pigment. They couldn't afford stone-carving and were 
unacquainted with the medium, while wood was exposed to them much later in the thirteenth century AD.

\section{The Päla-Sena School}

In the history of Bengal, many abrupt independent-rulers assuming imperial-titles are found till the second-half of sixth century AD. But, the region got its separate political-identity only in the seventh-century at Gaur, under the brief leadership of Śaśänka. Later on, following the rise and fall of several dynasties in rest of the country, Bengal came to witness the flowering of a considerable kingdom in the mid-eighth century AD. However, sculptural activities prior to that era have been suggested by several authentic evidences. (Saraswati, 1962) The three-hundred odd temples that already existed during the early-ninth century AD (Watters: 1961) must have led to the plastic-creation of gods or goddesses - either in clay, wood, stone or metal. However, the earliest surviving specimen of wooden idol - in the form of Bodhisattva Lokanātha - could only be retrieved from the era of the Pāla-dynasty.

The Päla-school: Pāla-rule in Bengal, beginning with king Gopāla in c. AD 750 and ending with Madanapāla in c. AD 1162, provided a stable and comprehensive socio-cultural establishment, which in turn worked as a major boost for the overall development of this region and the cultural flourish of its people. It gave birth to a new and significant school of sculpture following the classical grace and grandeur of the Gupta-phenomenon. In fact, the masterpieces of this period both on wood and stone - uttered the very legacy of the Guptas in a new style and aestheticlanguage.

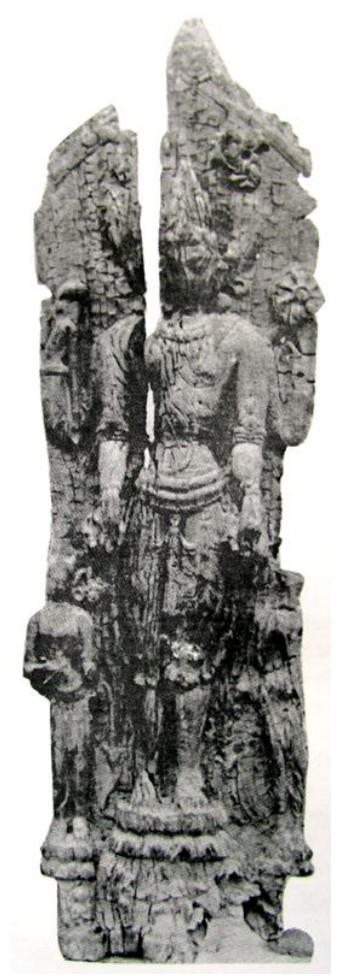

Fig 4. Vișnu. c. $12^{\text {th }}$ cent., $5^{2} \frac{1}{2} \mathrm{x}$ 16 in., BNM, Dhaka.

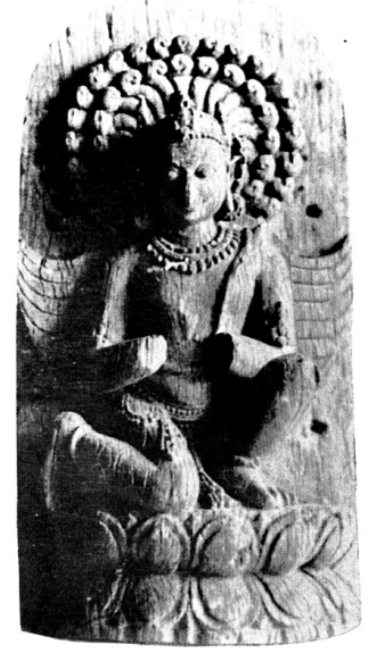

Fig 5. Garuda, c. $12^{\text {th }}$ cent., $26 \mathrm{x}$ $11^{3 / 4}$ in., BNM, Dhaka.

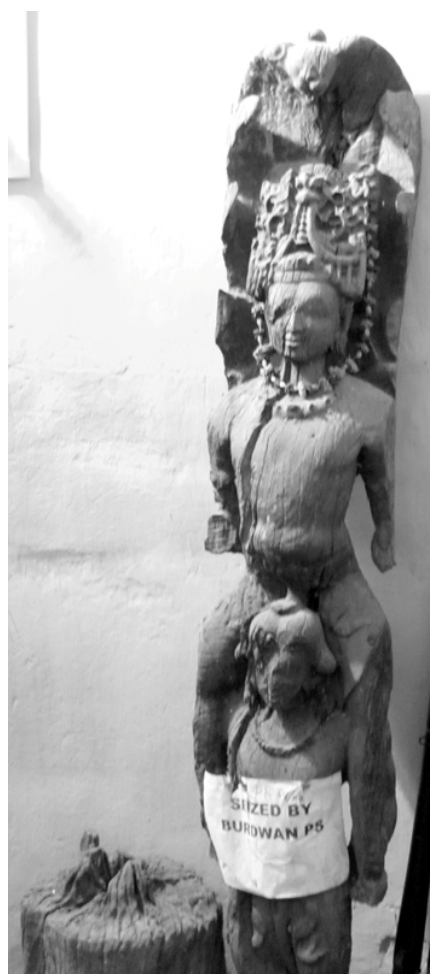

Fig 6. Viṣnu-on-Garuda. c. $12^{\text {th }}-13^{\text {th }}$ cent., $83^{1 / 2} \times 17 \times 9$ in. (pedestal 21 $1 / 2$ $x 17$ in.), SAM, Kolkata 
During this era, artists and craftsmen of this soil used to work simultaneously in all the four mediums - stone, clay, wood and paint. (Mitra, 1951) That is the reason, why all their works in wood closely resemble to their contemporary-executions in stone. Their similarities in content, iconography, approach, technique and style lead them to appear as works of the same artist or group. Although the number of available wooden-idols is extremely few in comparison to their stone-counterparts; but that doesn't prove that the former to be inferior to the latter. On the contrary, '...a first appearance in stone is almost tantamount to proof of an earlier currency in wood.' (Coomarswamy, 1972) Unfortunately, most of those wooden-pieces couldn't survive the ravages of time and hence perished forever. The surviving specimens, however, show us how a favorable socio-cultural-political-economic condition can instigate the aesthetic zeal of the people at large.

These wooden idols, assignable between ninth and twelfth century AD do not carry anything typical-to-Bengal; rather a feature inherited from the classical-Guptas is clearly evident in them. As a result of this, even after exhibiting all the skill and vitality of the local-artists, they could only be identified as a group of pan-Indian sculptures, produced on this soil.

Basically, the Pāla-rule provided a stable platform for the sculptors to cultivate their skills in the art of carving - both on stone and wood. They got the opportunity to make use of quality time and material to exercise their skills; while the iconographies, based on pan-Indian models, were already set in front of them. Hence, they found it easy to devote themselves in the very act of carving; and they ventured to carve-out every possible meticulous detail. In this process, they depicted everything on the material itself - the dress, the ornaments, accessories, and the backgrounds. In addition to the eyes, nose, lips, ears etc - they also carved all the other luxury and grandeur with extreme delicacy and understanding. The technique as a whole set a trend in the sculptural-art of Bengal and became a typical-identity of the Pâla-school, widely exercised on both stone and wood.

The Sena-school: Bengal in between eighth and thirteenth century AD was the cradle of two major socio-religious forces: Buddhism and Brahmanism. The latter in turn included three broad philosophical divisions in the form of Vaishnavism, Saivism and Saktism. Multiple variations of minor-groups, along with the faded-lineage of Jain-pantheon, also shared the panorama of earlymedieval religious-practices in Bengal.

Both Buddhism and Brahmanism were equally patronized by the Pāla-kings, who were Buddhist by religion and liberal in outlook. Both the pantheons got their deities sculpted - on wood and stone - with equal ease and excellence. Even the same artist or group, assigned with icons of both the sects, came-up with various scales of images - depicting the Buddhist-deities like Buddha, Bodhisattva, Lokanātha, Tārā, Mañjuśrī; Brahmanic-deities like Surya, Vișnu (see Fig 4 \& 6), Durgā-Mahișamarddinī; and demigods like Garuḍa (see Fig 5), Gaṇa etc. Such a multidimensional and aesthetically-secular practice came up with icons of all the religious-beliefs sculpted relentlessly in the same technique and style that was typical to that era.

But, things didn't remain the same forever. The glory of the Pāla-kings was shared by the Senas, who began to rule various parts of Bengal since late-eleventh century AD. Being known as Brahma-Kșatriyas, they were dedicated followers of the Brahmanic-ideologies and were not so open-minded like their Pāla-counterparts. Their reign was famous for building temples and monasteries; but none of the kings took much interest in promoting the other beliefs and cults.

During this time, Buddhism - after dominating Bengal for centuries - was in decline due to the loss of its institutions at Nālanda and Vikramaśilā. The Sena-kings added to this distress by 
withdrawing their state-promotion for the making of Buddhist-deities, even though the declining Păla-dynasty continued to mentor the tradition. The Brahmanic-idiom, on the contrary, was widely benefited from the augmented-interest of the emerging Sena-capital.

In any case, the carvers of Bengal went on exploring the same approach, technique and style - both on stone and wood - that were set by their Pāla-predecessors. Such meticulouslycarved pan-Indian icons gradually established a profound-signature of Bengal-sculpture between the eighth and the thirteenth century AD. These five-hundred odd years - together - constituted a significant style, what we know today as the Pāla-Sena school.

\section{The Age of Transformation}

The folk-tribal tradition of Bengal-sculpture, unlike the hieratic genre, has always remained virile without any promotion from the elite-class of the society or the royal-state. Their divine images were mostly made of clay and natural-pigment, since lavish exploration of wood, stone and metal was affordable only to the patronized-artists of hieratic-genre. However, things started to change - suddenly and with immediate effect - following the Islamic invasion in early-thirteenth century AD.

Bakhtiyar Khalji defeated King Lakșmaṇa Sena and founded the Islamic-rule at Lakshmanavati or Gaur. The kingdom thus became known as the Sultanate of Bengal - being ruled at regular intervals from Delhi (Bandyopadhyay, BS 1405) - while the Hindu politicalidentity got limited to mere chieftainships and baronships under the new rulers.

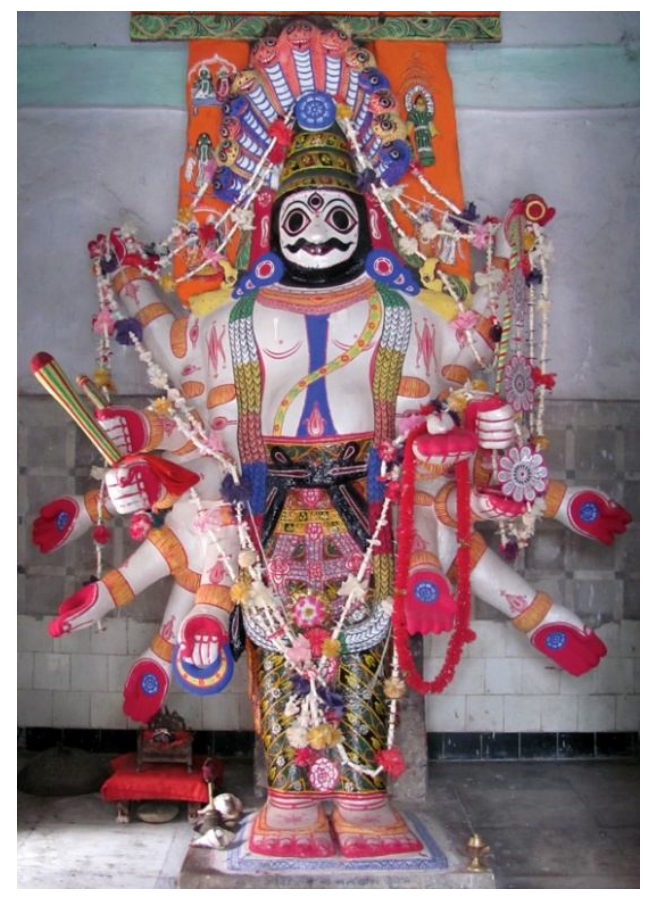

Fig 7. Balarāma, c. $14^{\text {th }}-15^{\text {th }}$ cent., height around 132 in., Boro, PS Raina, Bardhaman.

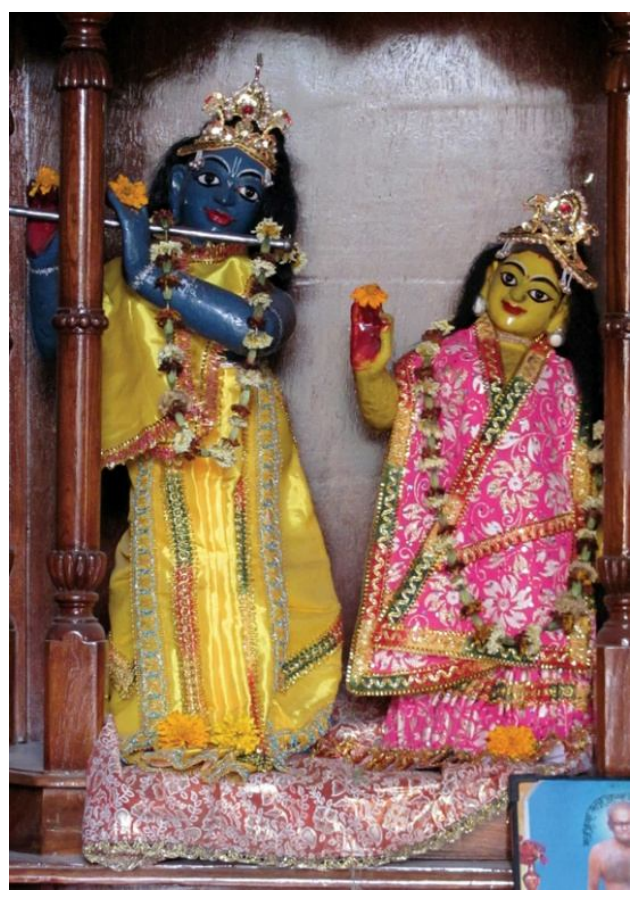

Fig 8. Krș̣na with Rādhā (later-addition), c. late-15 ${ }^{\text {th }}$ cent., height around 24 in., Saptagram, PS Magra, Hooghly. 
Renewed circumstances changed the royal-religion and the new-patrons were firmly against all sorts of image-worship. They withdrew the promotion of five-hundred long years resulting into several idols being left in the midway. Many of the highly-skilled artists took refuge to the neighboring Hindu-kings, while the rest were appointed in carving the royal-furniture and accessories. Their meticulous skill, which had remained a trademark of the Pāla-Sena school, got employed in the carving of those intricate-designs - both organic and geometric. Worshipping of idols became a secret-activity, while the hieratic-deities began to be made of clay and naturalpigment - instead of wood or stone.

In short, it was an era of acute turmoil in Bengal - be it in politics, economy, society or culture (Sen, 1999) - observing a silent-period in art; since specimens assignable to this era are extremely rare. Even the divine-images produced earlier were drowned into various water-bodies in order to save them from being humiliated by the Islamic-iconoclasts. (Dhamija, 1988) Fragilenature of wood and destructive agents like worms and white-ants were equally responsible for the ultimate disintegration of many of the specimens.

However the tradition sustained its demand, while their royal-patrons were replaced by local-chieftains and Zamindars. Even the poor common-folk began to initiate for raising funds to install the images of their beloved deities.

Stylistic Changes: In absence of the hieratic-artists, new commissions of wooden idols preferred the folk-tribal artisans, as they were easily-accessible and financially-affordable to the newpatrons. However, they were neither acquainted with the iconographic-specifications of the hieratic-order, nor habituated in working on permanent-materials like wood. New situations brought both the genres close to each other - forcing them to compromise with their habit and adjust with the new. The folk-tribal craftsmanship tried to meet up to the intricacies of hieraticaesthetics, while the latter became lenient in detail to adjust with the limits of the former. As a consequence of these, carving of the deities became much flat and simplistic, while the details became less intrinsic and meticulous. Paint was introduced for the convenience of depicting the facial-features and other intricacies. The basic dress-materials - along with headgear, earrings, necklaces, bangles, waist-bands, anklets and other ornaments - were still being carved on the surface, but the minute-motifs were replaced by the painted-ones (see Fig 7).

In these renewed circumstances, the hieratic-images refused to imitate the Păla-Sena idiom of large half-closed eyes - depicting a gesture of self-meditation. They rather followed the folk-tribal genre of eyes, split wide and open that look-up straight to the devotee. What was once private and restricted thus became open and public - resulting into a major-step towards the religious-democracy that took its final-shape in the sixteenth century.

Through this synthesis, sculpture in Bengal freed itself gradually from the shackles of panIndian hangover. The surviving-specimens together, although a few in number, exhibit an effort of blending between the hieratic and the folk-tribal, general and local. Their fresh look and appearance represent a tradition that was embodied with prominent-markers of a future-school of sculpture purely of Bengal-origin.

Other markers of transformation in society and culture: Besides the synthesis between hieratic and folk-tribal, traditional life in Bengal turned into a co-existence of different culturalsects and religious-beliefs. The multiplicity ranged from Saktism, Saivism and Vaishnavism up to the remote-practices of Tantric-Buddhism, other popular-cults and local-beliefs.

However, the last-quarter of fifteenth-century observed a period of socio-political turmoil that inevitably got reflected in the society at large. (Bandyopadhyay, BS 1405) On one hand the 
Brahmanic-conservatives were afflicted with several infirmities and limitations of their own; while Islamic-aggression was showing its full might on the other. The conventional-restraints of socioreligious hegemony also gave birth to a long history of poetic and philosophical revolt - with Candidāsa leading from the front.

Padāvalì-literature proclaimed the glory of humanity and exerted a strong influence on the common folk. The vast body of folk-literature - including Gopīcāndera Gāna, Mānikacandra Rājār Gāna etc - lavishly describes the spirit of human-life, including its pleasures and sorrows, love and hatred. In them, the popular-mind found Gods trembling before men and also being compelled to obey a common-woman like Maynāmatì. (Mookerjee, 1946) The Bāula-songs, Purva Bariga Gìtikās etc openly affirmed the freedom from social-restraints and lead towards free selfexpression.

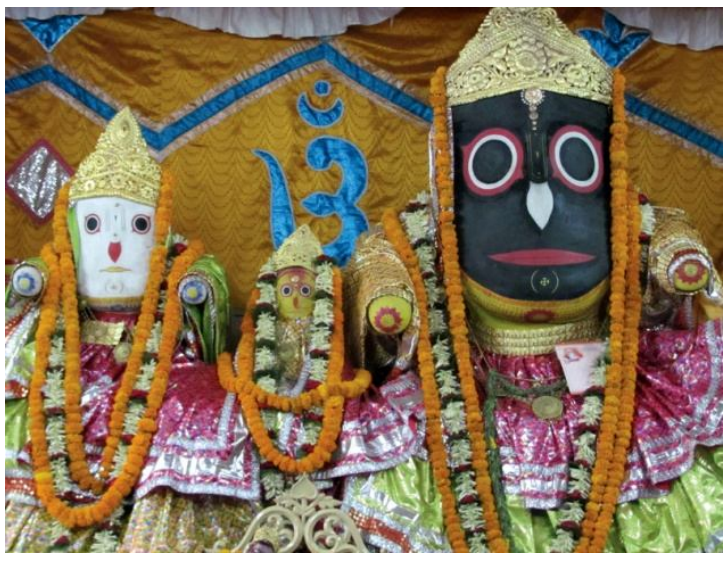

Fig 9. Jagannātha with Balarāma-Subhadrā (later-addition), c. $15^{\text {th }}-16^{\text {th }}$ cent., height around 54 in., Mahesh, PS Srirampur, Hooghly.

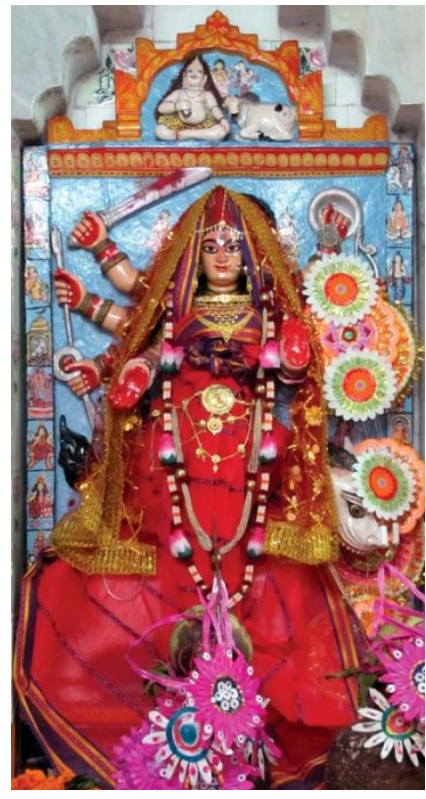

Fig 1o. Simhabāhinī, c. $16^{\text {th }}$ cent., height around 66 in., Nijabalia, PS Jagatvallabhpur, Howrah.

Later-verses of the Marigala-Kāvya tradition popularized many of the folk-deities and established them on the hieratic-level. By the end of fifteenth-century, the influence of folkBuddhism and reincarnation of Vaishnavism also added great dynamics to the common religiousoutlook. A renewed interest towards Vișnu-worship became evident; while the earlier-tradition of Bhägavata-centralism got shifted to the adoration of Krșna (see Fig 8) and Jagannätha (see Fig 9). All these together lead towards a major paradigmatic shift that came through a series of social, economic, political, ritual, religious and philosophical aspects. The era thus turned into an archetype and set the prelude for the upcoming-flourish of Gaudịya Vaișnava movement in the next century.

\section{The Renaissance}

In early-sixteenth century, Caitanya Mahāprabhu (see Fig 11) and his compeer Nityānanda revived the medieval Bhakti-movement (Sastri, 1966) and introduced Gauḍìya-Vaishnavism in Bengal. 
They together - known as Nitäi-Gaura - simplified the path of religion for the masses and opened-up the ritualistic-practices for all. The movement lead by them and carried forward by their associates thus brought a renaissance that resulted into multiple-perspectives in the life and culture of the Bengali folk. They accepted the spirit of this revival and reflected the same in their lifestyle, behavioral-pattern, dress-code, food-habit, music, poetry and art.

Following this, the tradition of woodcarving began to flourish, which in turn resulted into a renewed enthusiasm for the making of divine-images in wood. The widespread popularity of Gaurānga and his association with Nima-tree, perhaps, initiated the devotees to get their icons made in the same wood. The collective-emotion also got authenticated by texts like Manasāmangala - written by Vamísídāsa Cakrabartī in AD 1575-76 - prescribing Nima-wood as the only appropriate-material for fashioning the images of Nitäi-Gaura (see Fig 12). (Dasgupta, 1990)

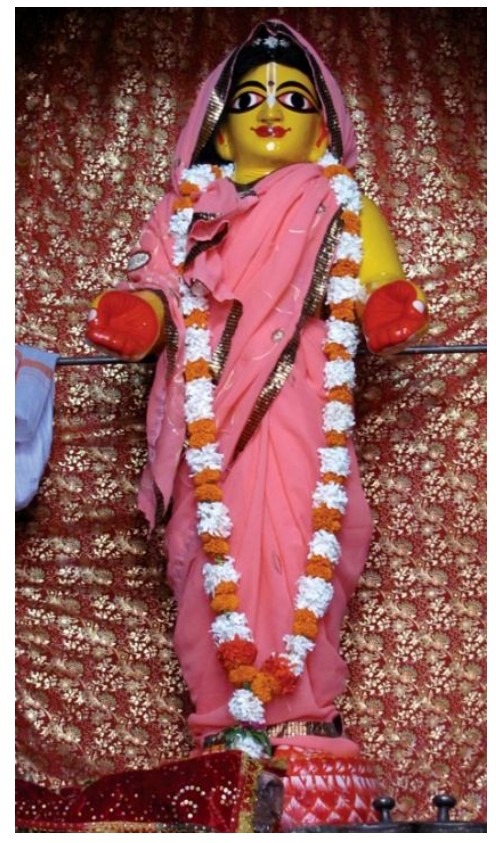

Fig 11. Gaurāniga, c. early- $16^{\text {th }}$ cent., height around 60 in., Nabadvip, Nadia.

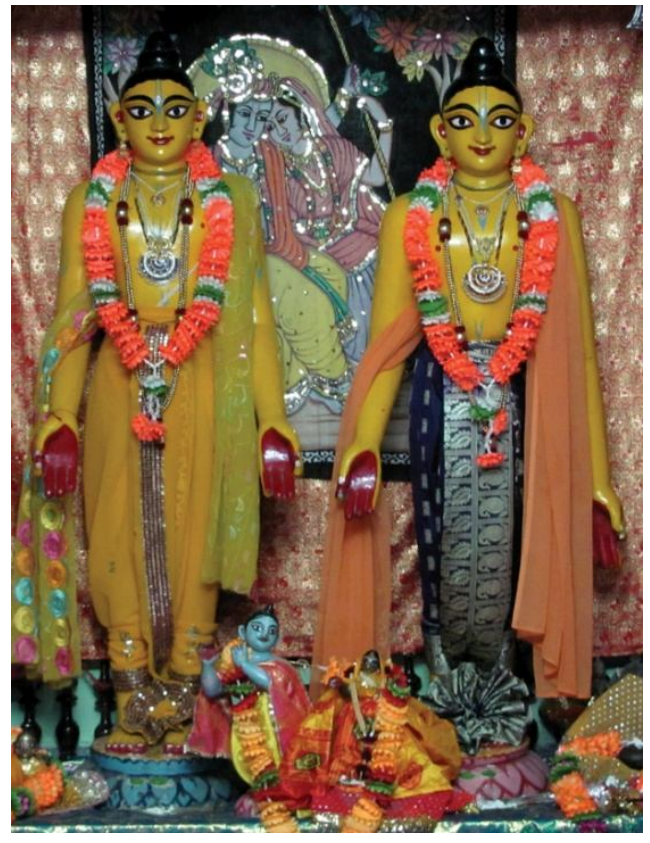

Fig 12. Nitäi-Gaura, c. mid-16 ${ }^{\text {th }}$ cent., height around 54 in., Atisara, PS Baruipur, South 24 Parganas.

In the mean time, Sakti-cult was firmly-grounded in the Rādha-region of Birbhum, Bankura, Bardhaman, Hooghly, Howrah and Nadia. It got flourished with the introduction of the Kālī-image by Krṣnānanda Āgamabāgīśa - author of Vrhat Tantrasāra - who was said to be contemporaneous to Śrì Caitanya.

In this situation, practitioners and followers of both the idioms got into conflict and convergence that included religion, philosophy, social-structure, economy and politics. The proceedings as a whole resulted into the production of numerous pieces of wooden idols all over the region. After remaining suppressed for three-hundred odd years, the tradition got revived by this renewed-interest and an immediate response from the masses. Although this time it became more democratic in content, less-intricate in technique, simple in style and tender in aesthetics. Thus, centuries of synthesis between the hieratic and the folk-tribal got reflected into a newdimension in the panorama of Bengal-sculpture. 
New-School of Bengal Sculpture: In this century, the art of making wooden-idols came up with many dynamics that took a major role in determining the future-course of aesthetic-progress in Bengal.

- Introduction of Rādhä-image beside the icon of Lord Krṣna;

- Popularization of the Jagannātha-triad;

- Deifying of mortal-humans like Nitāi-Gaura and others;

- Popularization of Nima-wood for the making of divine-images;

- Simplistic and shallow carving;

- Carving of the divine-images in nude - and then draping with real-clothes, ornaments and other accessories;

- Use of paint for portraying the facial-features and illuminating with other details;

- Combination of yellow, red and black as a most common visual-signature;

- Synthesis between the hieratic and the folk-tribal idioms - influencing the iconographies of all the sects like Śăkta, Śaiva, Vaișnava etc;

- Emerging of common people as collective-patrons of wooden idols.

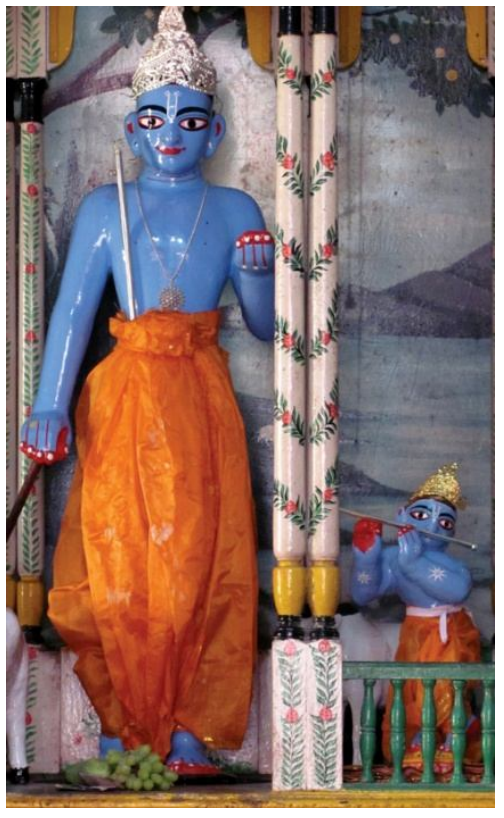

Fig 13. Gopīnātha (right, c. mid$16^{\text {th }}$ cent.) with Rākhāla Rāja (c. $17^{\text {th }}$ cent.), height around $18 \mathrm{in}$., Kalna, Bardhaman.

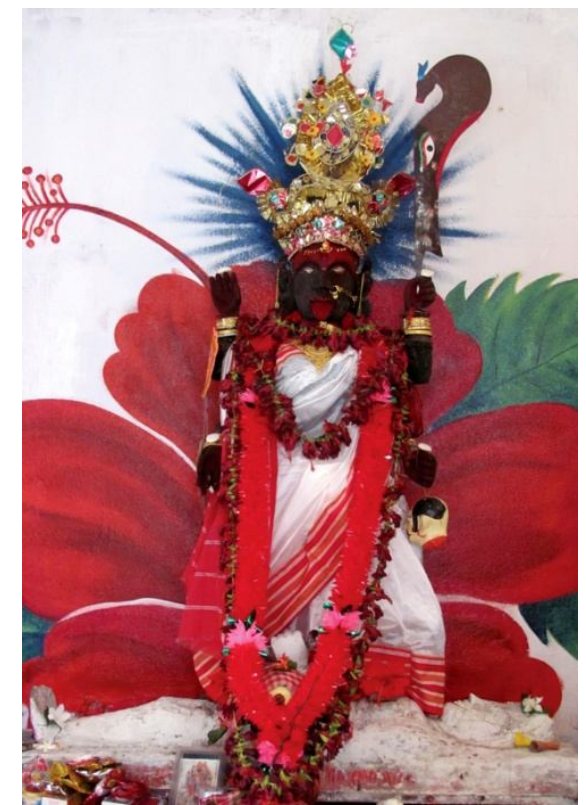

Fig $14 . K \bar{a} l i \overline{,}, \mathrm{c} .16^{\text {th }}$ cent., height around 60 in., Sardar-para (Garia-Fartabad), PS Sonarpur, 24 Pgns (S).

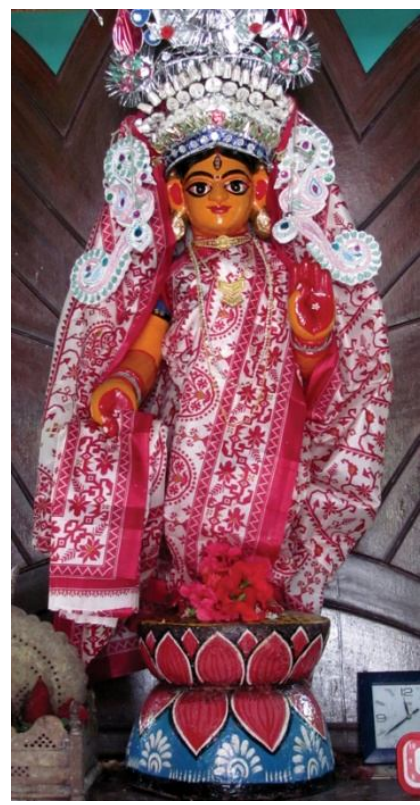

Fig 15. Jayacandī, c. $16^{\text {th }}-17^{\text {th }}$ cent., height around 42 in., Jainagar, 24 Pgns (S).

In this era, Saktism and Gauḍinya-Vaishnavism evolved as parallel-forces, while Saivism sustained as an age-old phenomenon. But, the wooden idols were more influenced by the Caitanya-phenomena that took a major role in determining the course of aesthetic-progress in Bengal. Vaișṇava-deities like Krșṇa (see Fig 13), Jagannātha and Mahāprabhu himself became extremely popular, while dual-images of Krșna-Rādhā, Nitāi-Gaura, and the triad of Balarāma- 
Subhadrā-Jagannātha were also produced. Images of other legends like Advaita, Srivāsa, Gadādhara, Abhirāma, Uddhāraṇa Datta, Yavana Haridāsa and Nityānanda's son Vìrabhadra were also installed in different corners. Śākta-deities like Simhabāhin̄̄ (see Fig 10), Kālì (see Fig 14) etc were produced, while the prevailing tradition of the folk-tribal (see Fig 15) and other hieratic deities also sustained in a full flow.

As a whole, the wooden idols of this century introduced a significant and uniform school of sculpture, devoid of any pan-Indian hegemony. It also marked the development of a Bengaliidiom - with its own aesthetic-vision, knowledge and wisdom - which spread uniformly all over the region. Besides wood, it also got reflected in the works of other medium like stone, metal, clay, paint etc.

It is true that many of the available-specimens remaining today are mere replicas that have been executed much later in time. But all of them refer to the era, which actually produced their historic, stylistic and aesthetic originals.

\section{Vaișnava-legacy and Beyond: changing faces of history}

In late-sixteenth century AD, the Șaḍa Gosvāmī at Vrindavan and Dvādaśa Gopāla in Bengal took the Bhakti-movement forward, while their successors like Śrīnivāsa Ācārya, Narottama Dāsa and Syamānanda Prabhu followed up the proceedings. In AD 1582 (Das, BS 1396) or 1583, (Unknown, 2008)) the Kheturi-festival was organized as an effort towards developing a unified-concept of Gauḍiya-Vaishnavism. (Bandyopadhyay, 1997) There Narottama installed images of Gaurāinga and Viṣnupriyā, Vallabhikānta, Brajamohana, Śrī Kṛṣna, Rādhākānta and Rādhāmohana; though the material used in their making remained unspecified. Śrinivāsa, on the other hand, converted Vìra Hāmbira of Vana-Vishnupur and initiated the tradition of late-medieval terracotta in Bengalarchitecture.

All these together resulted into an overwhelming response from the Bengali-artists and their connoisseurs in producing their deities in nima-wood. Neither the Islamic-rulers nor the mighty-British - could interrupt this long tradition of religious, as well as aesthetic virility.

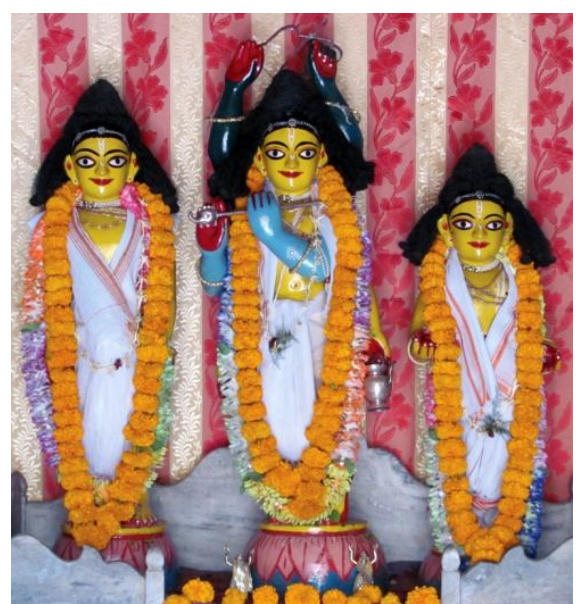

Fig 16. Nityānanda-ȘadabhujaGadādhara, c. mid-1 $7^{\text {th }}$ cent., height around 30,36 and 24 in., Saptagram, PS Magra, Hooghly.

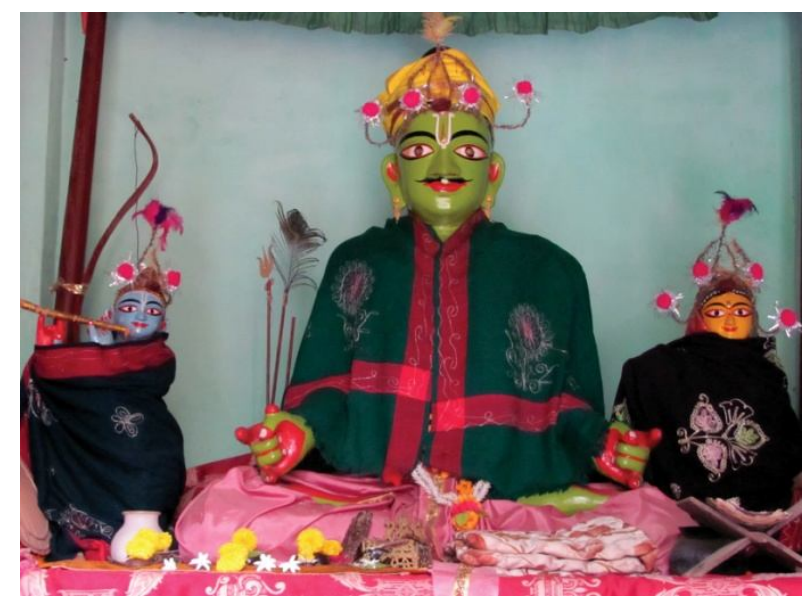

Fig 17. Raghunātha with Krsṣna and Sïtalā (Rādhā?!), c. late$18^{\text {th }}$ cent., height around 42 in., Raghunātha-talä (Pațha Mahal), Guptipara, PS Balagarh, Hooghly. 
Seventeenth Century AD: In this century, making of the Jagannātha-triad, Krṣna-Rādhā, NitāiGaura and other Vaișnava-associates continued in a full swing; while the revitalized Śăkta-wave also came up with significant sculptural-depictions of goddess Kālì, Canḍ̂̀ etc.

But, the most significant contribution of this era is Sadabhuja - a six-handed form of Gaurāinga - comprising Mahāprabhu, Rāma and Kṛșna embodied together (see Fig 16). The iconography was described in Caitanya Bhāgavata (Ghosh, 1995) and Caitanya Caritāmrta, (Mukhopadhyay, 1999) but appeared for the first-time in early-seventeenth century. Ancient deities like Cand̄i and Manasa began to be manifested in wood, while other hieratic-traditions also maintained a close proximity with the folk-tribal genres. The available specimens, however, are quantitatively large but aesthetically repetitive - imitating the guidelines of the earlier century.

Eighteenth and Nineteenth Centuries: Wooden idols of Bengal datable to eighteenth and nineteenth centuries are numerous in quantity and various in iconographies. Many of them represent the hieratic-tradition and are considered to belong to the higher order; though minordeities and semi-divine beings like Garuḍa and Hanumāna were also depicted in high-numbers. Even the folk-tribal icons - lately absorbed in the Brahmanic-idiom - are not rare.

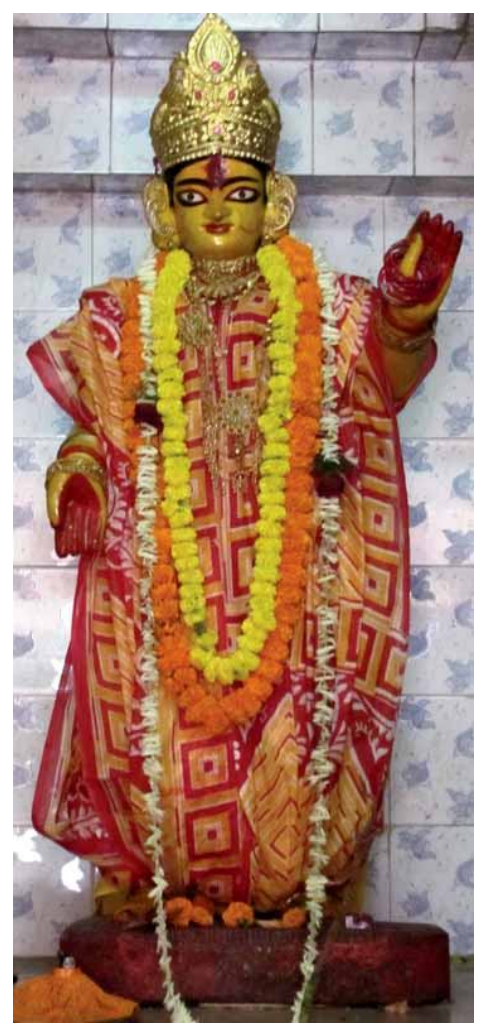

Fig 18. Mahāmāyāa, c. $18^{\text {th }}$ cent., height around 54 in., Mahāmāyātalā-Garia, PS Sonarpur, 24 Pgns (S).

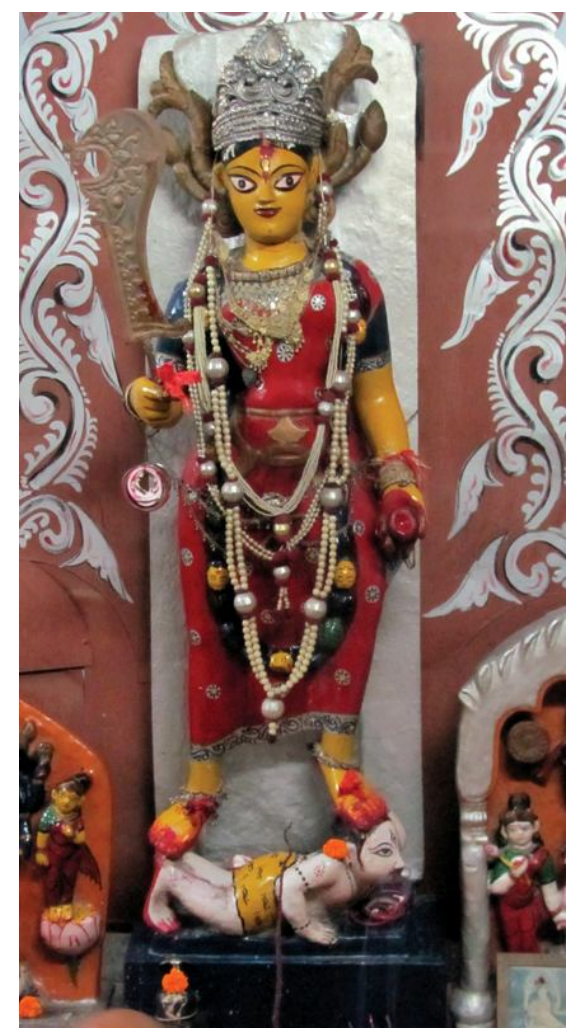

Fig 19. Viśáläkṣī, c. $18^{\text {th }}$ cent., height around 66 in., Viśálākși-talā, Baruipur, PS Baruipur, 24 Pgns (S).

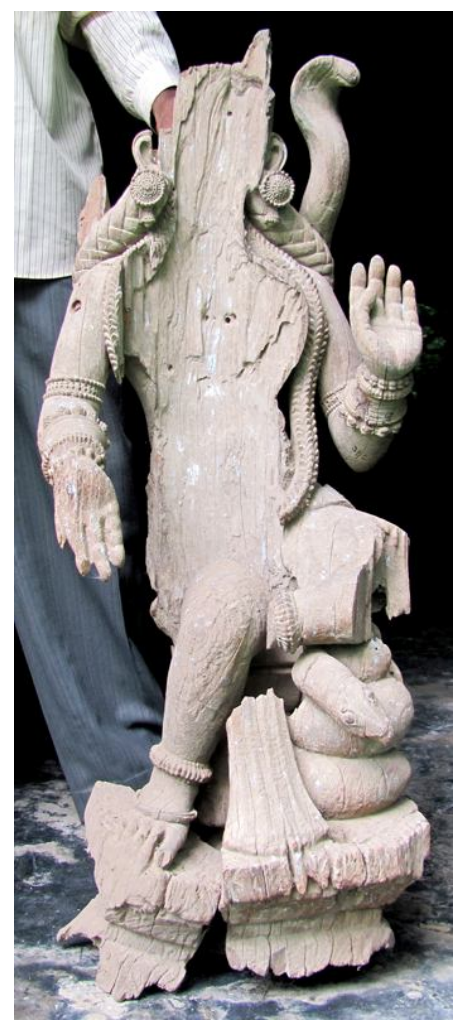

Fig 20. Manasā, c. $18^{\text {th }}-19^{\text {th }}$ cent., height around 42 in.,

Rajbalhat, PS Jangipara, Hooghly.

But, stylistically, these two centuries continued with the same legacy that was developed in the preceding era. They were to celebrate the multiple-dynamics of Bengal-school, paradigms of which were well-set in the sixteenth and seventeenth. The basic form and structure - along 
with the carving-techniques - remained almost the same; while the artisans were only to meet-up with the high-demand from the patrons and common-devotees.However, the era came up with some remarkable features that are prevalent in most of the living-specimens:

- Buddhist-divinities continued to be carved in a smaller scale and volume. Refer could be made to an eighteenth-century Goddess (Tārā?!) at the State Archaeological Museum in Kolkata, Khodā-Khudi or Pyakom-Pyakim from Achhipur in South 24 Parganas (Chattopadhyay, 2005) and the nineteenth-century Buddha at Ananda Niketan Keertishala in Nabasan, Howrah.

- Lord Siva, an important member of the Brahmanic-trinity, was stopped to be depicted individually. He remained either as a part of the Kālì-image or accompanied by his consort Pārvatī.

- Krșna - alone or with Rādhā - the Jagannātha-triad and Nitāi-Gaura remained as the most popular divine-motifs.

- Deities from other pantheons, especially Kālī and Viśālākșī (see Fig 19), became extremely popular and continued to be depicted in large numbers.

- Folk-tribal divinities like Pancānanda, Sìtalā and Dakșiṇa Rāya - who were earlier made of clay and paint - began to be depicted in wood as well.

- Ancient deities - like Mahāmāyā (see Fig 18), Canḍī, Manasā (see Fig 20), Hara-Pārvatī, Jagaddhātrī, Rämacandra-triad with Hanumāna - who have been portrayed in other mediums like stone etc, also began to be manifested in wood.

- Even Islamic-icons like Barkhān Gājī have been portrayed in wood, though it's one of the rare exceptions.

By the end of nineteenth century AD, the British and other Europeans in India succeeded to influence many indigenous-forms of aesthetic-expression, except a few like the wooden idols. Even today, the surviving-artisans of this tradition follow the norms that were set by the sixteenth-century visionaries; though the art has lost its dynamism and strength.

\section{Decline of the Past Glory}

Like every perishable being on earth, the tradition of making wooden idols in Bengal also began to decline in a natural curve. Several factors coincided and lead towards a gradual-disinterest of the Bengali-folk on this form of artistic-expression. By the beginning of twentieth-century, things started changing drastically and turning in a different direction.

- The Permanent Settlement Act, introduced in 1793 and made permanent in 180o, began to show its marvels. The local-Zamindars lost their property and authority; and hence couldn't remain as regular-patrons like before.

- The village-landlords began to spend most of their time and money in Kolkata and other metropolis - reducing or cutting-off their ancestral-connection with the rural life and culture.

- The newly English-educated elite-class began to deviate from their traditional beliefs, customs, rituals and religious-practices.

- Most of the new-generation artisans refused to take-up their ancestral-profession; and hence many of the technical-secrets that were to be passed through generations were lost forever. 
- People from other castes and clans joined this trade; but they lacked the hereditaryknowledge and traditional-skills.

- Environmental awareness put restrictions on the cutting of trees; and hence good quality wood was not as available as before.

- Inferior and slack productions generated a sort of disinterest among the patrons.

- Easily-available, cheaper and more-handy mediums like plaster were introduced and people began to prefer them to wood.

- Modern Bengali city-dwellers - rich, in-secured and hence religious - were more influenced by the Europeans and the elite-culture of North and Western India. With these new associations, they changed their taste and began to prefer marble or metal over wood for the manifestation of their beloved-deity.

Thus the age-old tradition began to die down - gradually but surely - yet kept itself alive till the first-quarter of the twentieth-century. The next one-hundred odd years, however, tell us a story of absolute-degeneration; though abrupt-glimpses of the legacy still remained visible.

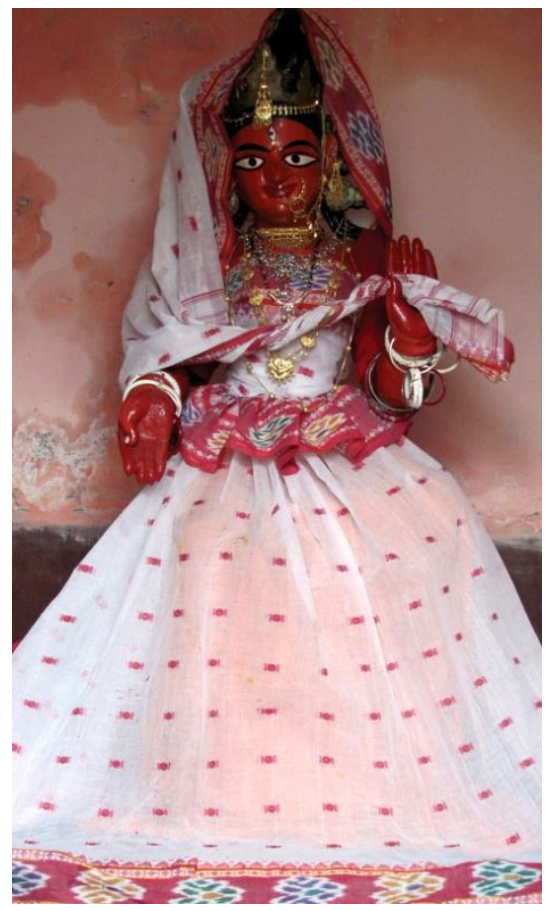

Fig 21. Mangalacanḍī, c. $19^{\text {th }}$ cent., height around 48 in., Bariya (Paschim-para), PS Diamond Harbor, 24 Pgns (S).

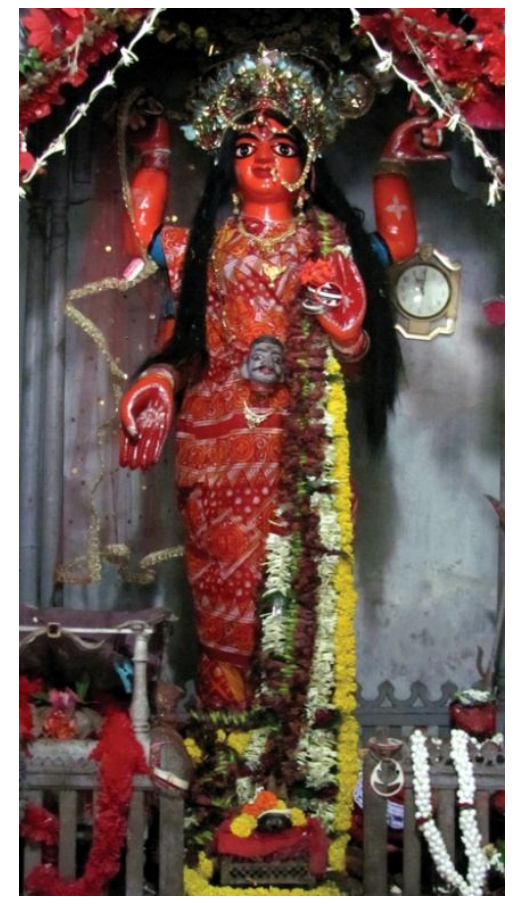

Fig 22. Tripurāsundarī, c. $19^{\text {th }}-20^{\text {th }}$ cent., height around 60 in.,

Chhatrabhog, PS Mathurapur, 24 Pgns (S).

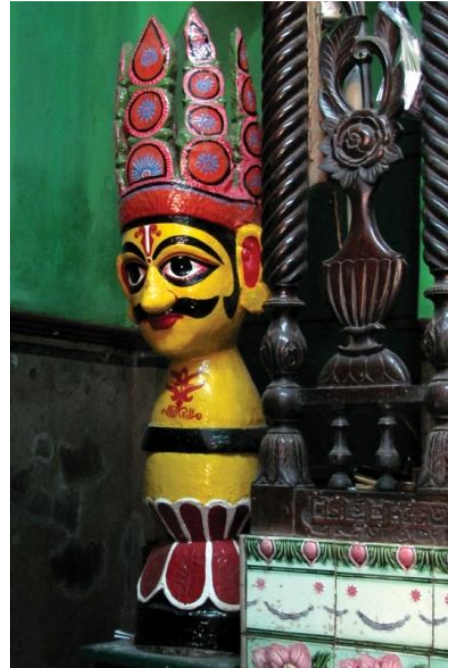

Fig 23. Dakșina Rāya, c. $19^{\text {th }}$ $20^{\text {th }}$ cent., height around 30 in., Dhanvantarī Kālī Temple, Majilpur, PS Jainagar, 24 Pgns

(S).

But now there is rarely any demand for such wooden-images and hardly any artists are surviving on this form of artistic-practice. Even the Sūtradharas of Natungram - for instance - do not make such divinities anymore, while those who are in-business at Ekchakra or Nabadvip are not Sūtradhara at all. In any case, most of the occasional-orders from a handful of devotees local, national or international - favored the working-artisans surviving even today. But, as a whole, this very tradition of Indian art could be considered as a dead one. 


\section{Last Few Words, But Not The Least}

The tradition of making wooden idols in Bengal belongs to an old-ancestry, which evolved through the ages as a collective visual-emotion of the entire clan. In this process, it democratized the portrayal of divine-images - maintaining a close-proximity with the other contemporaneous art-practices. It introduced a uniform-school of Bengal-sculpture, with an aesthetic-identity of its own - irrespective of any religious-bias and independent of any pan-Indian hegemony. It also introduced a unique group of artisans in the form of Sütradharas - producing innumerable sculptural-pieces of artistic excellence. Besides influencing the other mediums of visualexpression, it also provided a distinct identity to the Bengali-intelligentsia as a whole.

It's true that the Sūtradharas have left their ancestral-profession and merely engaged themselves in making household accessories. It is also true that a few wooden deities are occasionally made today and that too by the artisans of some other caste or lineage. True again, there is hardly anybody left to know the traditional-procedure of carving; while present-day Bengali-mass has lost interest in this form of wooden-sculpture. Even it is true that the making of wooden idols is already a dead-art...

Even after that, ignoring an episode that comprises a history of twelve-hundred long years and illustrated by seven-hundred odd living-specimens is very difficult. Without an in-depth study of such a comprehensive tradition, the history of Bengal and thus of Indian art would always remain incomplete.

\section{References}

Agrawala, Vasudeva S. (1963). Matsya Purana: A Study. Benares: All India KashirajTrust. Preface

Asher, Frederich M. (1980). The Art of Eastern India, 300-80o. Minnepolis: University of Minnesota Press. 4

Bandyopadhyay, Debasish. (1997). Caitanya Carcāra Pāncśo Bachara. Kolkata: Ananda Publishers. 38

Bandyopadhyay, Rakhaldas. (BS 1405). Bāngālāra Itihāsa, part 2. Kolkata: Dey’s Publishing. 4-5, 12, 129-32

Banerji, R D. (1933). Eastern Indian School of Mediaeval Sculpture. Delhi: Archaeological Survey of India. 18

Chakraborti, Shyamal Kanti. (2001). Wood Carvings of Bengal in Gurusaday Museum. Kolkata: Gurusaday Museum. 2001), 11-2

Chattopadhyay, Sagar. (2005). Dakṣiṇa Cabbiśa Pargaṇā Jelāra Purākīrti. Kolkata: Pratnatattva O Samigrahālaya Adhikāra, Paścimbañga Sarakāra. 50-1

Coomarswamy, Ananda K. (1972). Introduction to Indian Art. New Delhi: Munshiram Manoharlal. 11, 17

Craven, Roy C. (2001). Indian Art: A Concise History. London: Thames \& Hudson. 48

Dasgupta, Kalyan Kumar. (1990). Wood Carvings of Eastern India. Kolkata: Firma KLM Pvt. Ltd. viii-ix, 13, 50

Das, Sri Krisna Chaitanya. (BS 1396). Śrī Śrīnivāsa Caritāmṛta. Jajigram: Śrīpāṭa of Śrīnivāsa Ācārya. 10, Itihāsa Prasañga

Dhamija, Ram (ed). Sixty Years of Writing on Art \& Crafts in India (from Roopa-lekha 1928-1988). New Delhi: Sterling Publishers Private Limited. 42

Ghosh, Barid Baran (ed.). (1995). Vṛndāvana Dāsa viracita Śrī Śrī Caitaṇya Bhāgavat. Kolkata: Dey’s Publishing. 146, 156

Havell, E B. (1915). The Ancient and Medieval Architecture of India: A Study of Indo-Aryan Civilisation. 20

Mitra, A (ed). (1951). Census 1951, West Bengal: The Tribes and Castes of West Bengal. New Delhi: Govt of India. 321-2 
Mookerjee, Ajit. (1946). Folk Art of Bengal: a study of an art for, and of, the people. Kolkata: University of Calcutta. 4

Mukhopadhyay, Upendra Nath (ed.). (1999). Paramabhāgavata Kavirāja Kṛṣnadāsa Gosvāmī kṛta Śrī Śrī Caitanya Caritāmṛta. Kolkata: Reflect Publication. 80-1

Samaddar, Jogindranath (tr) \& Ghosh, Baridbaran (ed). (1988) Hiuyena Sānera Driștite Bauddhabhārata. Kolkata: Sarat Publishing House. 1

Saraswati, S. K. (1962). Early Sculptures of Bengal. Delhi: Sambodhi Publications. 6 \& 85

Sastri, K S Ramaswami. (1966). Indian Aesthetics: Music and Dance. Tirupati: Sri Venkateswara University. 7,10

Sen, Dinesh Chandra. (1999). Vṛhat Banga, Vol. 2. Kolkata: Dey’s Publishing. 649-74

Spooner, Brainerd D (ed.). Archaeological Survey of India, Annual Report, 1921-22. Delhi: Swati Publications. 81

Tarkaratna, Panchanan \& Nyayateertha, Sreejib (tr. \& ed.). (BS 1394). Matsyapurāṇam. Kolkata: Nava Bharat Publishers. 892

Unknown. (2008). Mahābāhu Maheśa-carita O Śrīpāṭa Pal-pārā Paricaya. Ekchakra: Parātattva Prakāśana. 6 Watters, Thomas. (1961). On Yuan Chwang's Travels in India, vol. 2. Delhi: Munshi Ram Manohar Lal. 175, $181,185,190-1$

\section{Photo-Credit}

Sankalia, H. D. (December, 1982). A Unique Wooden Image of the Buddhist Goddess Tara from the Kanheri Caves. Marg, 36/1 (Fig 1)

Banu, Zinat Mahrukh. (2003). Bāmiālaseśera Dāruśilpa. Dhaka: BNM （Fig 2, 3)

Bhattashali, Nalini Kanta. (1929/2008). Iconography of Buddhist and Brahmanical Sculptures in the Dacca Museum. Dhaka: BNM (Fig 4, 5)

Sanjay Sen Gupta is Assistant Professor at the School of Fine Arts, Amity University Kolkata, India, and a member of the Ediorial Board of The Chitrolekha Journal on Art and Design. He did PhD (Fine Arts) in Visual Arts from the University of Calcutta (Govt. College of Art \& Craft), India, 2014. He is a practicing artist, with keen interest in various genres of Indian and Bengal art. He has presented quite a number of papers in various seminars and published in many journals both in the national and international level. 